\title{
DIFFERENTIATED APPROACH TO EMPLOYEE MOTIVATION IN TERMS OF FINANCE
}

\author{
Miloš HITKA (D) 1 , Silvia LORINCOVÁ (D) 2*, Marek POTKÁNY(D)3, \\ Žaneta BALÁŽOVÁ (D) ${ }^{4}$, Zdeněk CAHA (D) 5 \\ ${ }^{1,2,3}$ Department of Business Economics, Faculty of Wood Sciences and Technology, \\ Technical University in Zvolen, Zvolen, Slovak Republic \\ ${ }^{4}$ Institute of Foreign Languages, Technical University in Zvolen, Zvolen, Slovak Republic \\ ${ }^{5}$ Faculty of Corporate Strategy, Institute of Technology and Business in Ceske Budejovice, \\ Ceske Budejovice, Czech Republic
}

Received 21 May 2020; accepted 09 September 2020

\begin{abstract}
Motivating the employees is considered one of the essential manager's skills. Knowledge of powerful motivation factors allow managers to motivate employees effectively. It results in motivated employees able to affect a success of enterprises and its competitive advantage. Following the research carried out using 34,000 Slovak employees, the importance of motivation factors relating to finance was defined. Tukey's HSD test, as a part of the ANOVA analysis, was used for extensive investigation into the most important motivation factors relating to finance. It is supposed that motivation of employees of different gender, age and job position will differ. The suppositions were confirmed by the results achieved in the research showing significant differences between individual employee categories of managers, blue-collar workers and white-collar workers. Taking into consideration the results, managers are suggested to concentrate on motivating the employees as parts and not as a whole because of the differences in the needs of employees in terms of gender, age and mainly job position.
\end{abstract}

Keywords: human resources management, employee motivation, motivation factors relating to finance, gender, age, job position, Tukey's HSD test.

JEL Classification: J24, O15, Q56.

\section{Introduction}

Each company must possess tangible and intangible assets as well as human resources in order to run the company in fully-fledged way. It can be said that human resources are the key factor for the business success. Therefore, human resources must be motivated to be effective with perfect results. Motivated human resources can bring success. Thus, the employee motivation is the aim of the research.

*Corresponding author. E-mail: silvia.lorincova@tuzvo.sk

Copyright (c) 2020 The Author(s). Published by Vilnius Gediminas Technical University

This is an Open Access article distributed under the terms of the Creative Commons Attribution License (http://creativecommons. org/licenses/by/4.0/), which permits unrestricted use, distribution, and reproduction in any medium, provided the original author and source are credited. 
Currently, the issue of the motivation is focused on identifying the motivation factors in various countries (Hondgesberg, 2013; Monster, 2009) and on analyzing the perception of their preferences in terms of age and gender (Malchrowicz-Mośko et al., 2019; Hayes et al., 2018; Fapohunda, 2017; King et al., 2017; Joniakova \& Blstakova, 2015; Almobaireek \& Manolova, 2013). Following the results presented in actual research studies, it can be stated that there is a research gap in identifying the motivation factors relating to different job positions.

Following the evaluation of thirty motivation factors, the main objective of the research is to define the most important motivation factors relating to finance affecting the motivation of the Slovak employees to improve job performance in terms of gender, age and job position. The originality of the research lies in the fact that it is primary research because no one has examined such a comparison of factors in terms of statistical significance in terms of different job positions.

The structure of the paper is as follows: firstly, the review of the literature associated with the issue is presented. Then, the methodology is defined. It is followed by the research findings and discussion. Finally, conclusions, limitation and future research direction are provided.

\section{Literature review}

Human resources and their management are a part of management system in each company all over the world determining the business success very often (Kucharčíková \& Mičiak, 2018; Miklosik et al., 2018). It is generally accepted reason that human factor is becoming the most considerable competitive advantage associated with the development of information technology and globalisation (Pogodina et al., 2020; Kohnová et al., 2019). The business existence, its prosperity and dynamic development relate especially to the quality of human potential (Potkány et al., 2019; Kampf \& Lizbetinova, 2015). It is not a product differentiating one business from another, but it is about the quality employees. Employees becomes the most essential and the most valuable production factor, the main asset that must be used deliberately in order to achieve the goals.

Prosperous enterprises are aware of the fact that employees and their motivation are the most profitable capital allowing the enterprises to succeed and the meet their goals (Faletar et al., 2016). Systematic developing and using the human potential is a prerequisite for playing to strengths and competitive advantages of businesses (Nedeliaková et al., 2018; Štarchoň et al., 2017). All enterprises are interested in abilities, ways to improve the quality of their employees (Anguelov et al., 2020; Cakir \& Kozak, 2017).

Human resources are a key to a success of enterprises (Jung et al., 2020; Piotrowska, 2019). An ability to create a competitive advantage determines the way of running an enterprise and its prosperity (Moresová et al., 2019; Palus et al., 2019). Employees must be motivated to work effectively and to obtain perfect results. Motivating the employees is considered one of the most difficult and at the same time the most important manager's skills (Remenova \& Jankelova, 2019; Stacho et al., 2019; Williams, 2013).

Motivation is a topic studied for decades. It is an important role belonging to the human resource management in each enterprise (Dar et al., 2014). In human resource management, 
the motivation is linked with individual wishes to improve the job performance and to meet the required task with maximum effort applied (Sheehan et al., 2016; Ayub, 2010). Motivation is often defined as an inner power that manages, supports and encourages the behavior despite changing circumstances (Diefendorff \& Seaton, 2015). Motivation relates to reasons of behavior (Guay et al., 2010). It is something keeping us working. Motivation is considered a stimulus, incentive, reason allowing an individual to make decisions or arrangement (Niermann \& Schmutte, 2014). It can be defined also as a process encouraging permanent target activity (Yukseloglu \& Karaguven, 2013).

Motivated employees have their own goals directed in accordance with the enterprise goals (Kumar et al., 2019; Linhartová \& Urbancová, 2012; Kamalian et al., 2010). The job performance of employees motivated in the right way is higher than those with no motivation (Faletar et al., 2016). Managers must be familiar with the employee motivation, with specific motivation factors and through stimuli they must raise employees' willingness, determination to get involved in meeting goals associated with enterprise missions and goals (Stachova et al., 2018; Zaborova et al., 2017). Knowledge about factors motivating employees allow managers to create the motivation programme covering enterprise as well as employees' needs.

All facts affecting the employee performance and running the business must be taken into account, the employers must be aware of them when creating the motivation programme (Miklosik et al. 2019; Szierbowski-Seibel, 2018). The facts relate to information connected with technical, technological conditions for work, type of workplace, working conditions and sanitary facility, satisfaction or dissatisfaction in the workplaces, value orientation, relations to work, co-workers, supervisors and enterprise itself (Laužikas \& Miliūtè, 2020; Kaylene et al., 2010). The information relating to social, demographic and qualification characteristics of employees, appraisal system, social welfare and system of personnel management are considered important as well (Damij et al., 2015; Bakotic \& Babic, 2013) because in accordance with the research of Chatzopoulou et al. (2015) and Kampkötter (2014) employees can be motivated by basic salary or reward. However, employee motivation is affected by changes in personal, mental, financial, social as well as other factors (Hitka et al., 2020; Kropivšek et al., 2011). As there are various employees cooperating in the workplace, their motivation is affected also by gender and age (Malchrowicz-Mośko et al., 2019; Fapohunda, 2017; Joniakova \& Blstakova, 2015). The preferences of employees are different and therefore their motivation differ as well. Women are motivated more by family needs; they try to find work-family balance (Almobaireek \& Manolova, 2013). On the contrary, men are directed by economic welfare and professional success at work (Bailyn, 1993; Buttner, 1993). Men prefer to be independent, women prefer to work interactively, teamwork and ask for help colleagues (Peterson, 2004). When the focus is put on the age, younger employees are motivated more by increasing the profit. On the other hand, the older employees are motivated by accomplishments they have already achieved (Freund, 2006). Older employees want to be more accepted, especially their opinions due to their experience, whereas younger employees want to be heard (Deal, 2007). Employees from the Generation Baby boomers are motivated by their status, benefits and prestige (Hayes et al., 2018; King et al., 2017). Generation X put the emphasis on the work-life balance (Kaylene et al., 2010). Employees of the Generation Y are cooperative and optimistic (Zemke et al., 2000). Generation Z is very 
active and goal-directed (Singh, 2014). There are differences between people and they must be respected when the enterprise wants to achieve positive results. Owing to the effective motivating the employees, another variables affecting the level of motivation were spread. The main objective of the research is to define the most important motivation factors relating to finance affecting the motivation of the Slovak employees to improve job performance with the focus put on gender, age and job position.

\section{Methodology}

Motivation was investigated following the research using anonymous questionnaires in the social survey. The questionnaire consisted of two parts. The socio-demographic features of respondents (gender, age, job position) were investigated in the first part. In the second part of the questionnaire the respondents expressed their opinion through 30 motivation factors following the long-lasting research (Hitka, 2009). Following motivation factors were investigated: atmosphere in the workplace, basic salary, career advancement, communication in the workplace, competences, fair appraisal system, free time, fringe benefits, good work team, individual decision-making, information about performance result, job performance, job security, mental effort, mission of the company, name of the company, opportunity to apply one's own ability, personal growth, physical effort at work, prestige, recognition, region's development, relation to the environment, selfactualization, social benefits, stress, supervisor's approach, work environment, working hours, workload and type of work. Motivation factors were in the alphabetical order not to affect the respondents' decisions. Likert scale was used to evaluate the importance of studied motivation factors: 5 - very important, 4 - fairly important, 3 - important, 2 - slightly important, 1 - not at all important. Total of 34,615 employees working in Slovakia resulting from the random selection participated in the research. Composition of the sample set is presented in Table 1.

Table 1. Composition of the sample set

\begin{tabular}{|c|c|c|c|c|c|}
\hline \multirow{2}{*}{ Gender } & \multirow{2}{*}{ Age } & \multicolumn{3}{|c|}{ Job category } & \multirow{2}{*}{ Total } \\
\hline & & manager & $\mathrm{BCW}$ & WCW & \\
\hline \multirow[t]{4}{*}{ Male } & $<30$ & 309 & 3,187 & 1,125 & 4,621 \\
\hline & $<40$ & 593 & 3,522 & 1,523 & 5,638 \\
\hline & $<50$ & 620 & 2,997 & 1,132 & 4,749 \\
\hline & $50+$ & 362 & 1,641 & 699 & 2,702 \\
\hline \multicolumn{2}{|l|}{ Male total } & 1,884 & 11,347 & 4,479 & 17,710 \\
\hline \multirow[t]{4}{*}{ Female } & $<30$ & 371 & 1,811 & 1,574 & 3,756 \\
\hline & $<40$ & 578 & 2,132 & 2,402 & 5,112 \\
\hline & $<50$ & 548 & 2,089 & 2,342 & 4,979 \\
\hline & $50+$ & 326 & 1,185 & 1,547 & 3,058 \\
\hline \multicolumn{2}{|l|}{ Female total } & 1,823 & 7,217 & 7,865 & 16,905 \\
\hline \multicolumn{2}{|l|}{ Total } & 3,707 & 18,564 & 12,344 & 34,615 \\
\hline
\end{tabular}


The objective was to define the most important motivation factors relating to finance affecting the motivation of the Slovak employees to improve job performance with the focus put on gender, age and job position. The research was focused on the group aged up to 30, up to 40 , up to 50 and $50+$. When investigating the job position, the focus was given on managers, blue-collar workers (BCW) and white-collar workers (WCW).

The hypothesis in which it is supposed that the motivation needs of employees of different gender, age, and job position are different is verified using the Tukey's unequal N HSD test set for unequal sample size at the level of significance $\alpha=5 \%$. Statistical software Statistics 12.0 was used to process and evaluate the data.

\section{Results and discussion}

In the first step, based on an extensive database of input data, the importance of motivation factors was defined following obtained values using the method of weighted arithmetic mean. The results are presented in Table 2.

Table 2. Importance of motivation factors

\begin{tabular}{|c|l|c|}
\hline No. & \multicolumn{1}{|c|}{ Motivation factor } & Mean \\
\hline 1. & Basic salary & 4.509 \\
\hline 2. & Good work team & 4.427 \\
\hline 3. & Atmosphere in the workplace & 4.416 \\
\hline 4. & Fair appraisal system & 4.410 \\
\hline 5. & Job security & 4.398 \\
\hline 6. & Supervisor's approach & 4.370 \\
\hline 7. & Fringe benefits & 4.344 \\
\hline 8. & Communication in the workplace & 4.256 \\
\hline 9. & Working hours & 4.199 \\
\hline 10. & Work environment & 4.180 \\
\hline 11. & Social benefits & 4.152 \\
\hline 12. & Recognition & 4.123 \\
\hline 13. & Job performance & 4.119 \\
\hline 14. & Stress & 4.085 \\
\hline 15. & Workload and type of work & 4.085 \\
\hline 16. & Free time & 4.064 \\
\hline 17. & Opportunity to apply one's own ability & 4.036 \\
\hline 18. & Personal growth & 4.034 \\
\hline 19. & Mental effort & 4.019 \\
\hline 20. & Career advancement & 4.011 \\
\hline 21. & Selfactualization & 3.984 \\
\hline 22. & Individual decision-making & 3.977 \\
\hline 23. & Information about performance result & 3.969 \\
\hline 24. & Relation to the environment & 3.899 \\
\hline 25. & Mission of the company & 3.869 \\
\hline 26. & Competences & 3.864 \\
\hline & & \\
\hline
\end{tabular}


End of Table 2

\begin{tabular}{|c|l|c|}
\hline No. & \multicolumn{1}{|c|}{ Motivation factor } & Mean \\
\hline 27. & Name of the company & 3.854 \\
\hline 28. & Physical effort at work & 3.817 \\
\hline 29. & Region's development & 3.778 \\
\hline 30. & Prestige & 3.714 \\
\hline
\end{tabular}

The results presented in Table 2 show that basic salary and fair appraisal system are the most important motivation factors relating to finance affecting the motivation of the Slovak employees to improve job performance.

Consequently, the most important motivation factor basic salary was investigated using Tukey's HSD test. Individual groups of respondents, quantities, arithmetic means of evaluation of the motivation factor basic salary are presented in Table 3.

Table 3. Descriptive statistics of the motivation factor basic salary

\begin{tabular}{|c|c|c|c|c|c|c|c|}
\hline \multirow{2}{*}{ Gender } & \multirow{2}{*}{ Age } & \multirow{2}{*}{$\begin{array}{c}\text { Job } \\
\text { category }\end{array}$} & \multirow{2}{*}{ Total } & \multirow{2}{*}{ Mean } & \multirow{2}{*}{$\begin{array}{l}\text { Standard } \\
\text { deviation }\end{array}$} & \multicolumn{2}{|c|}{ Confidence interval } \\
\hline & & & & & & $-95.00 \%$ & $95.00 \%$ \\
\hline \multirow{12}{*}{ Male } & \multirow{3}{*}{$<30$} & manager & 309 & 4.47249191 & 0.909931104 & 4.37063576 & 4.57434806 \\
\hline & & $\mathrm{BCW}$ & 3,187 & 4.44838406 & 0.886931551 & 4.4175797 & 4.47918842 \\
\hline & & WCW & 1,125 & 4.48444444 & 0.813026603 & 4.43688415 & 4.53200473 \\
\hline & \multirow{3}{*}{$<40$} & manager & 593 & 4.53962901 & 0.757082235 & 4.47856959 & 4.60068842 \\
\hline & & BCW & 3,522 & 4.50397501 & 0.824304954 & 4.47674232 & 4.53120771 \\
\hline & & WCW & 1,523 & 4.49441891 & 0.763276085 & 4.45605478 & 4.53278304 \\
\hline & \multirow{3}{*}{$<50$} & manager & 620 & 4.52580645 & 0.782055509 & 4.4641271 & 4.58748581 \\
\hline & & BCW & 2,997 & 4.50717384 & 0.819304747 & 4.47782941 & 4.53651827 \\
\hline & & WCW & 1,132 & 4.50265018 & 0.772534754 & 4.45759882 & 4.54770154 \\
\hline & \multirow{3}{*}{$50+$} & manager & 362 & 4.45027624 & 0.821465774 & 4.36536959 & 4.5351829 \\
\hline & & $\mathrm{BCW}$ & 1,641 & 4.42839732 & 0.874376672 & 4.38606101 & 4.47073363 \\
\hline & & WCW & 699 & 4.4806867 & 0.776157302 & 4.42304816 & 4.53832523 \\
\hline \multirow{12}{*}{ Female } & \multirow{3}{*}{$<30$} & manager & 371 & 4.48247978 & 0.81644602 & 4.39912864 & 4.56583092 \\
\hline & & BCW & 1,811 & 4.50027609 & 0.847730106 & 4.46120667 & 4.53934551 \\
\hline & & WCW & 1,574 & 4.59720457 & 0.678723841 & 4.56364835 & 4.6307608 \\
\hline & \multirow{3}{*}{$<40$} & manager & 578 & 4.53633218 & 0.760526389 & 4.47420089 & 4.59846347 \\
\hline & & BCW & 2,132 & 4.51876173 & 0.825522468 & 4.48370026 & 4.5538232 \\
\hline & & WCW & 2,402 & 4.57493755 & 0.730433007 & 4.54571212 & 4.60416299 \\
\hline & \multirow{3}{*}{$<50$} & manager & 548 & 4.5419708 & 0.795364393 & 4.47523084 & 4.60871077 \\
\hline & & BCW & 2,089 & 4.50359023 & 0.821240731 & 4.46835305 & 4.53882742 \\
\hline & & WCW & 2,342 & 4.55678907 & 0.723070442 & 4.52748959 & 4.58608855 \\
\hline & \multirow{3}{*}{$50+$} & manager & 326 & 4.53680982 & 0.762704262 & 4.45370699 & 4.61991264 \\
\hline & & BCW & 1,185 & 4.44810127 & 0.914900225 & 4.39595697 & 4.50024556 \\
\hline & & WCW & 1,547 & 4.55462185 & 0.728346074 & 4.51829892 & 4.59094478 \\
\hline
\end{tabular}


Table 3 shows that in terms of gender, the motivation factor basic salary was considered the most important by men at the age up to 40 in the position of a manager. Following the statistical testing, the results can be generalised. The fact that the motivation factor basic salary will be evaluated by Slovak employees in the range between $4.48-4.60$ with the $95 \%$ of reliability can be stated. Basic salary was considered the most important motivation factor by women - white-collar workers aged up to 30. Following the obtained results, it can be mentioned that the motivation factor basic salary will be evaluated in the range between $4.56-4.63$ by women - white-collar workers aged up to 30. The results also show that the motivation factor basic salary was ranking higher by women than men. Therefore, the finding that the motivation factor basic salary is more important for women than men emerges.

Table 4 determines the effects of gender, age, job position on the statistically significant differences in the motivation factor basic salary. The power of statistically significant differences at the level of significance of $5 \%$ is determined by the p-level.

Table 4. One dimensional results of the motivation factor basic salary

\begin{tabular}{|l|c|c|c|c|c|}
\hline \multicolumn{1}{|c|}{ Effect } & $\begin{array}{c}\text { Degree of } \\
\text { freedom }\end{array}$ & SS effect & MS effect & F-test & p-level \\
\hline Absolute term & 1 & 410924.6 & 410924.6 & 633921.6 & 0.000000 \\
\hline Gender & 1 & 9.3 & 9.3 & 14.3 & 0.000158 \\
\hline Age & 3 & 6.6 & 2.2 & 3.4 & 0.016555 \\
\hline Job category & 2 & 15.4 & 7.7 & 11.9 & 0.000007 \\
\hline Gender ${ }^{*}$ age & 3 & 1.4 & 0.5 & 0.7 & 0.540125 \\
\hline $\begin{array}{l}\text { Gender }{ }^{*} \text { job } \\
\text { category }\end{array}$ & 2 & 6.0 & 3.0 & 4.6 & 0.009915 \\
\hline $\begin{array}{l}\text { Age }{ }^{*} \text { job } \\
\text { category }\end{array}$ & 6 & 4.8 & 0.8 & 1.2 & 0.283305 \\
\hline $\begin{array}{l}\text { Gender }{ }^{*} \text { age } \\
\text { job category }\end{array}$ & 6 & 1.2 & 0.2 & 0.3 & 0.930197 \\
\hline Error & 34591 & 22422.8 & & & \\
\hline Total & 34614 & 22486.9 & & & \\
\hline
\end{tabular}

Although the results of Table 4 presenting one dimensional results of the motivation factor basic salary and determining the statistical dependence between gender, age, and job position do not show a significant dependence, the Tuckey HSD test was used to perform further analysis.

The results of the Tukey's HSD test (Table 5, Figure 1) showed several statistically significant differences (highlighted in red). The differences between men - blue-collar workers aged up to 30 , men - blue-collar workers aged 50+ and women - white-collar workers at all ages were identified. Further statistically significant differences were determined between women working in the job position as a blue-collar worker abed 50+ and women - whitecollar workers at the age up to 30 and up to 40 . 


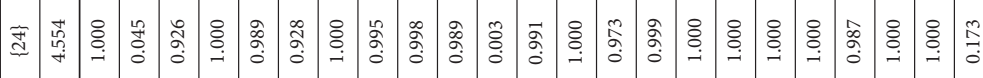

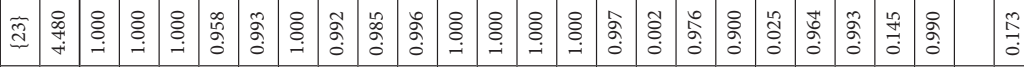

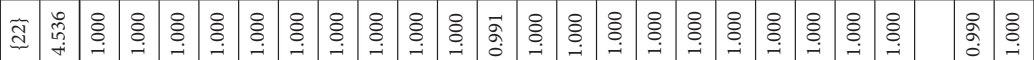

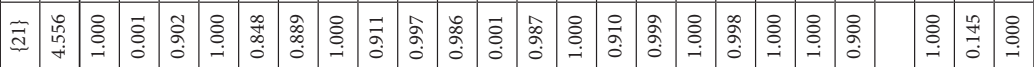

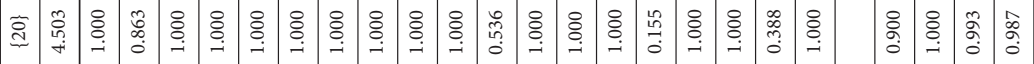

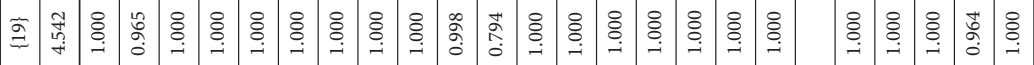

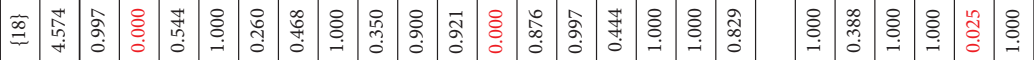

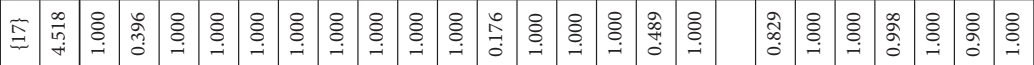

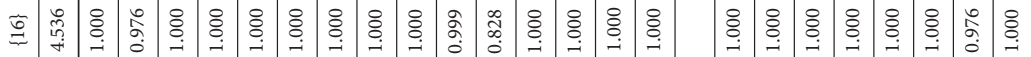

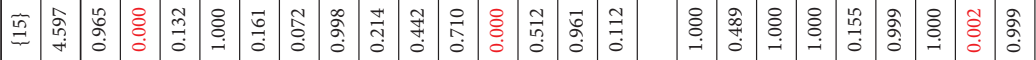
茟离

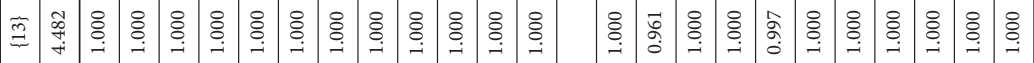

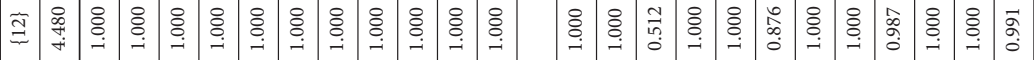

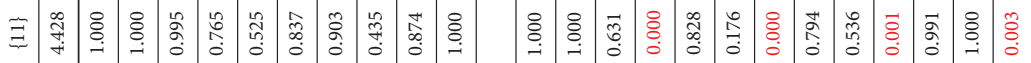

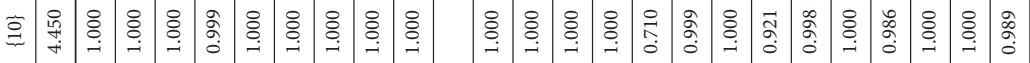

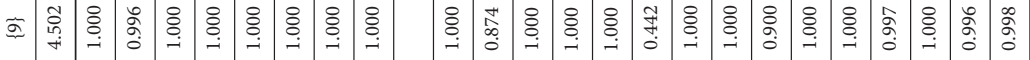

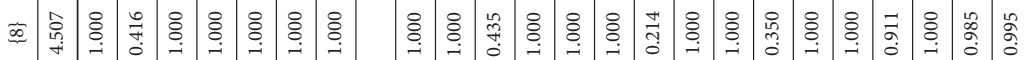

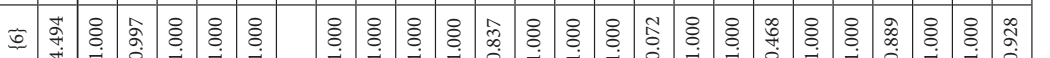

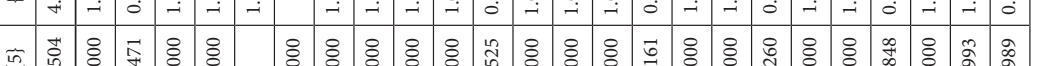

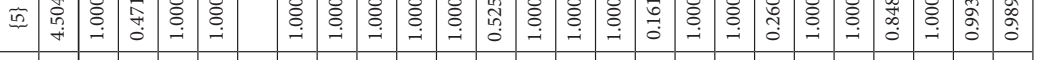

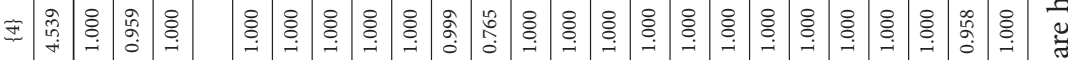

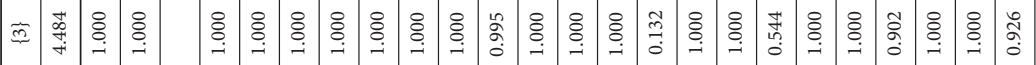

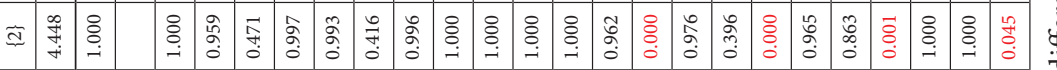

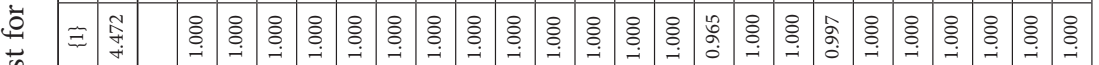

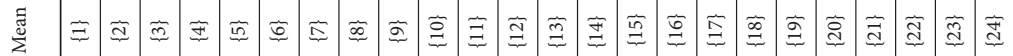

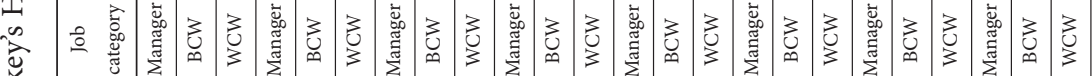
尝 官

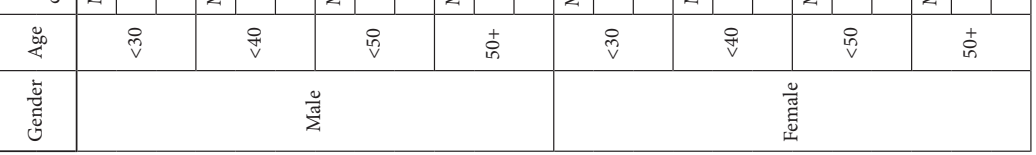



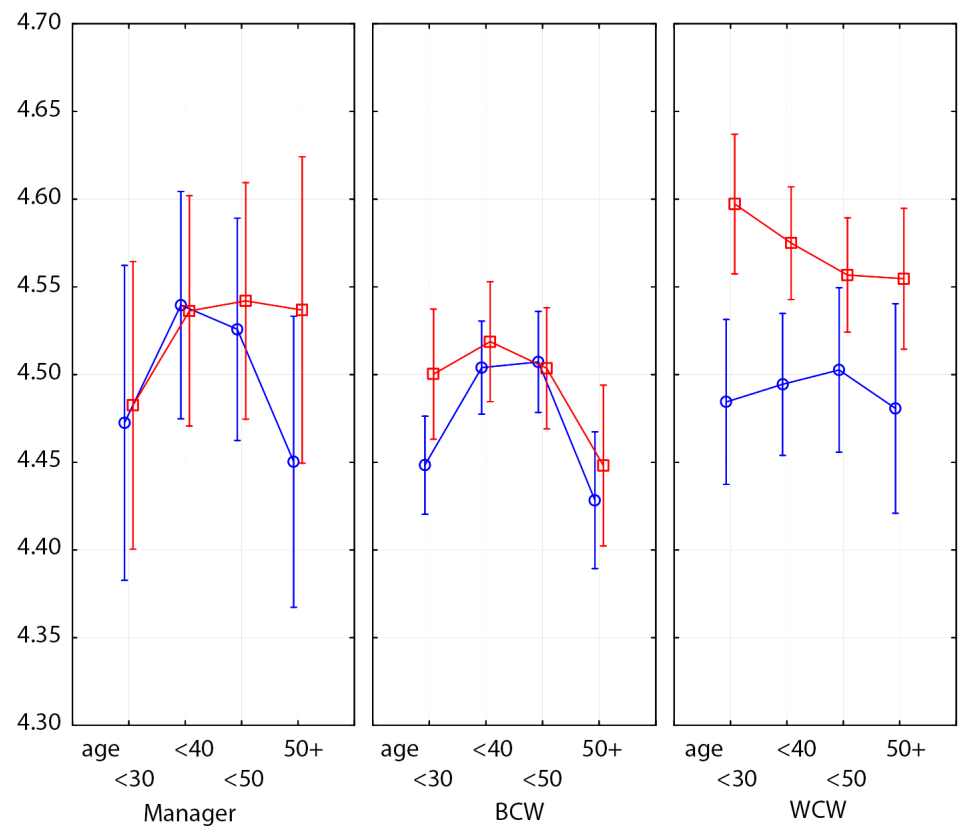

Figure 1. Tukey's HSD test for motivation factor basic salary

Consequently, the second most important motivation factor relating to finance fair appraisal system was investigated. Table 6 shows that two groups of men assessed the mentioned motivation factor in a very similar way. The motivation factor received the highest average grade, at the level of 4.44. The evaluation was given by men - white collar workers aged up to 30 and men - managers at the age up to 40 . Women - managers aged up to 40 definitely considered the motivation factor fair appraisal system the most important with the highest average grade. Following the results, it can be stated that the studied motivation factor was assessed by women managers aged up to 40 will in the range from 4.45 to 4.58 with $95 \%$ of reliability. Following the results, the finding that the motivation factor fair appraisal system was considered more important by women than by men emerged. When investigating the women, the motivation factor received higher average grade.

Table 6. Descriptive statistics of the motivation factor fair appraisal system

\begin{tabular}{|c|c|c|c|c|c|c|c|}
\hline \multirow[t]{2}{*}{ Gender } & \multirow[t]{2}{*}{ Age } & \multirow{2}{*}{$\begin{array}{c}\text { Job } \\
\text { category }\end{array}$} & \multirow[t]{2}{*}{ Total } & \multirow[t]{2}{*}{ Mean } & \multirow{2}{*}{$\begin{array}{l}\text { Standard } \\
\text { deviation }\end{array}$} & $\begin{array}{l}\text { Confidence } \\
\text { interval }\end{array}$ & $\begin{array}{l}\text { Confidence } \\
\text { interval }\end{array}$ \\
\hline & & & & & & $-95.00 \%$ & $95.00 \%$ \\
\hline \multirow{6}{*}{ Male } & \multirow{3}{*}{$<30$} & manager & 309 & 4.38187702 & 0.891770658 & 4.28205372 & 4.48170033 \\
\hline & & BCW & 3,187 & 4.35770317 & 0.877317286 & 4.32723273 & 4.38817361 \\
\hline & & WCW & 1,125 & 4.43644444 & 0.791809596 & 4.3901253 & 4.48276359 \\
\hline & \multirow{3}{*}{$<40$} & manager & 593 & 4.43676223 & 0.718809291 & 4.37878957 & 4.49473489 \\
\hline & & BCW & 3,522 & 4.37024418 & 0.806675076 & 4.34359392 & 4.39689443 \\
\hline & & WCW & 1,523 & 4.38345371 & 0.774114319 & 4.34454483 & 4.42236259 \\
\hline
\end{tabular}


End of Table 6

\begin{tabular}{|c|c|c|c|c|c|c|c|}
\hline \multirow{2}{*}{ Gender } & \multirow{2}{*}{ Age } & \multirow{2}{*}{$\begin{array}{c}\text { Job } \\
\text { category }\end{array}$} & \multirow{2}{*}{ Total } & \multirow{2}{*}{ Mean } & \multirow{2}{*}{$\begin{array}{l}\text { Standard } \\
\text { deviation }\end{array}$} & $\begin{array}{l}\text { Confidence } \\
\text { interval }\end{array}$ & $\begin{array}{c}\text { Confidence } \\
\text { interval }\end{array}$ \\
\hline & & & & & & $-95.00 \%$ & $95.00 \%$ \\
\hline & \multirow{3}{*}{$<50$} & manager & 620 & 4.39516129 & 0.852806337 & 4.32790194 & 4.46242064 \\
\hline & & $\mathrm{BCW}$ & 2,997 & 4.36736737 & 0.83492853 & 4.33746335 & 4.39727138 \\
\hline & & WCW & 1,132 & 4.3860424 & 0.835919666 & 4.33729467 & 4.43479014 \\
\hline & \multirow{3}{*}{$50+$} & manager & 362 & 4.41160221 & 0.807978344 & 4.32808961 & 4.49511481 \\
\hline & & $\mathrm{BCW}$ & 1,641 & 4.3308958 & 0.85301602 & 4.28959374 & 4.37219785 \\
\hline & & WCW & 699 & 4.43204578 & 0.747030583 & 4.37657023 & 4.48752133 \\
\hline \multirow{12}{*}{ Female } & \multirow{3}{*}{$<30$} & manager & 371 & 4.38274933 & 0.911858209 & 4.28965754 & 4.47584112 \\
\hline & & BCW & 1,811 & 4.39646604 & 0.865335301 & 4.35658525 & 4.43634684 \\
\hline & & WCW & 1,574 & 4.50825921 & 0.756154082 & 4.47087482 & 4.5456436 \\
\hline & & manager & 578 & 4.51384083 & 0.754408503 & 4.45220934 & 4.57547232 \\
\hline & $<40$ & BCW & 2,132 & 4.38227017 & 0.877116616 & 4.3450174 & 4.41952294 \\
\hline & & WCW & 2,402 & 4.48792673 & 0.738693725 & 4.45837077 & 4.51748268 \\
\hline & & manager & 548 & 4.40510949 & 0.802265637 & 4.33779043 & 4.47242854 \\
\hline & $<50$ & BCW & 2,089 & 4.40162757 & 0.825258135 & 4.36621801 & 4.43703713 \\
\hline & & WCW & 2,342 & 4.48761742 & 0.738615982 & 4.45768803 & 4.51754682 \\
\hline & & manager & 326 & 4.44171779 & 0.815980087 & 4.35281014 & 4.53062545 \\
\hline & $50+$ & BCW & 1,185 & 4.38396624 & 0.880674342 & 4.33377263 & 4.43415986 \\
\hline & & WCW & 1,547 & 4.49450549 & 0.738299547 & 4.45768618 & 4.53132481 \\
\hline
\end{tabular}

Table 7 of the one-dimensional results of the motivation factor fair appraisal system determines statistically significant differences cause especially by the age and job position, gender and job position respectively.

Table 7. One-dimensional results of the motivation factor fair appraisal system

\begin{tabular}{|l|c|c|c|c|c|}
\hline \multicolumn{1}{|c|}{ Effect } & $\begin{array}{c}\text { Degree of } \\
\text { freedom }\end{array}$ & SS effect & MS effect & F-test & p-level \\
\hline Absolute term & 1 & $394,274.3$ & $394,274.3$ & $594,845.4$ & 0.000000 \\
\hline Gender & 1 & 12.5 & 12.5 & 18.8 & 0.000014 \\
\hline Age & 3 & 1.8 & 0.6 & 0.9 & 0.436081 \\
\hline Job category & 2 & 40.5 & 20.3 & 30.6 & 0.000000 \\
\hline Gender * age & 3 & 0.5 & 0.2 & 0.3 & 0.847411 \\
\hline Gender * job category & 2 & 4.6 & 2.3 & 3.5 & 0.030736 \\
\hline Age job category & 6 & 8.8 & 1.5 & 2.2 & 0.038754 \\
\hline $\begin{array}{l}\text { Gender * age * job } \\
\text { category }\end{array}$ & 6 & 2.6 & 0.4 & 0.7 & 0.684183 \\
\hline Error & 34591 & 22927,5 & 0,7 & & \\
\hline Total & 34614 & 23025,9 & & & \\
\hline
\end{tabular}




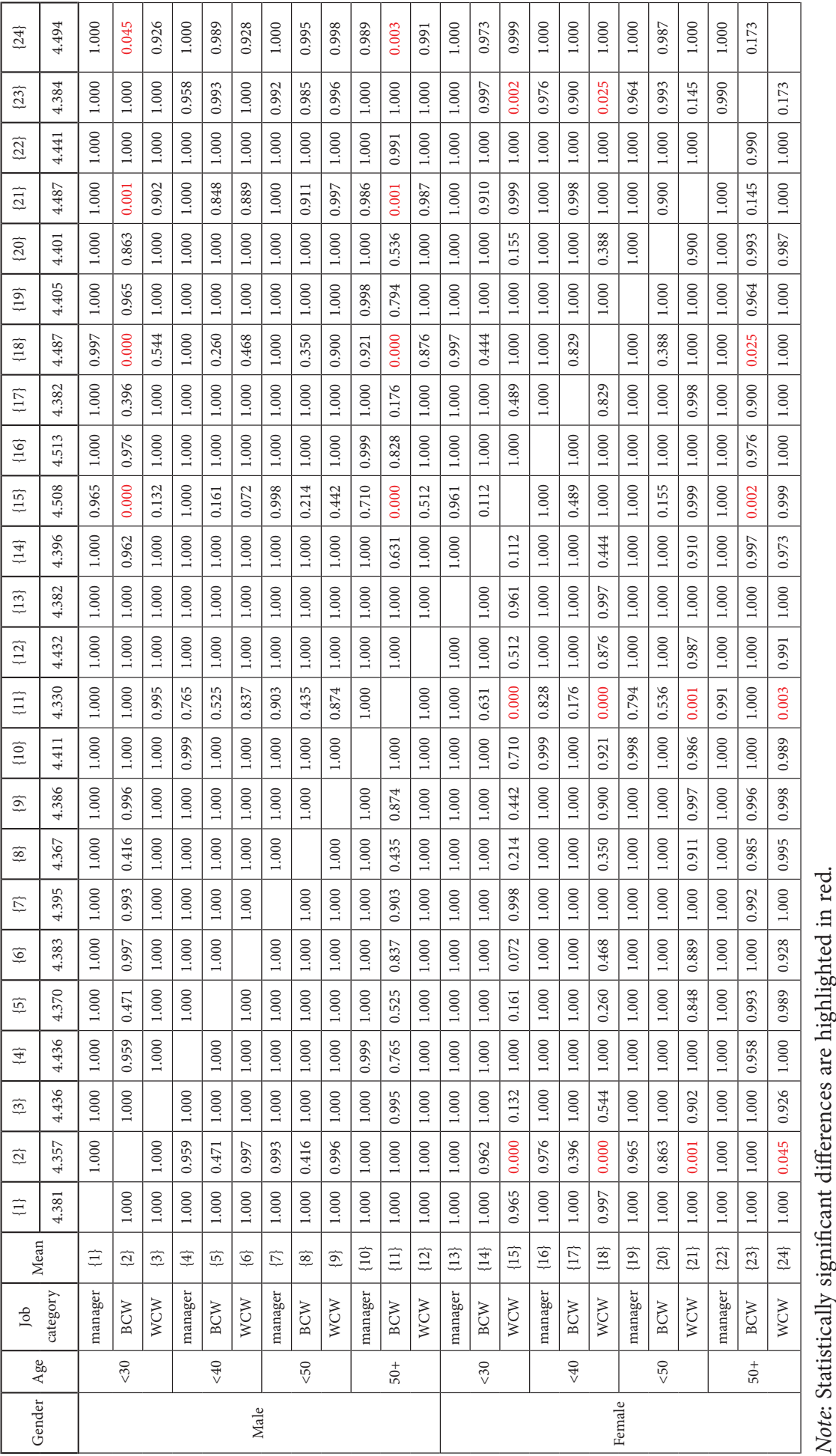


Although the results of Table 7 presenting one dimensional results of the motivation factor fair appraisal system and determining the statistical dependence between gender, age, and job position do not show a significant dependence, the Tuckey HSD test was used to perform further analysis.

In Table 8 and Figure 2, it can be observed that the number of statistically significant differences was fallen down in comparison to the previous motivation factor analysed. Moreover, statistically significant differences between women - blue collar workers at the age up to 50 and women - white collar workers at the age up to 30 were observed. Similar results were obtained when the focus was given on women - blue collar workers aged 50+ and women white collar workers aged up to 30 .
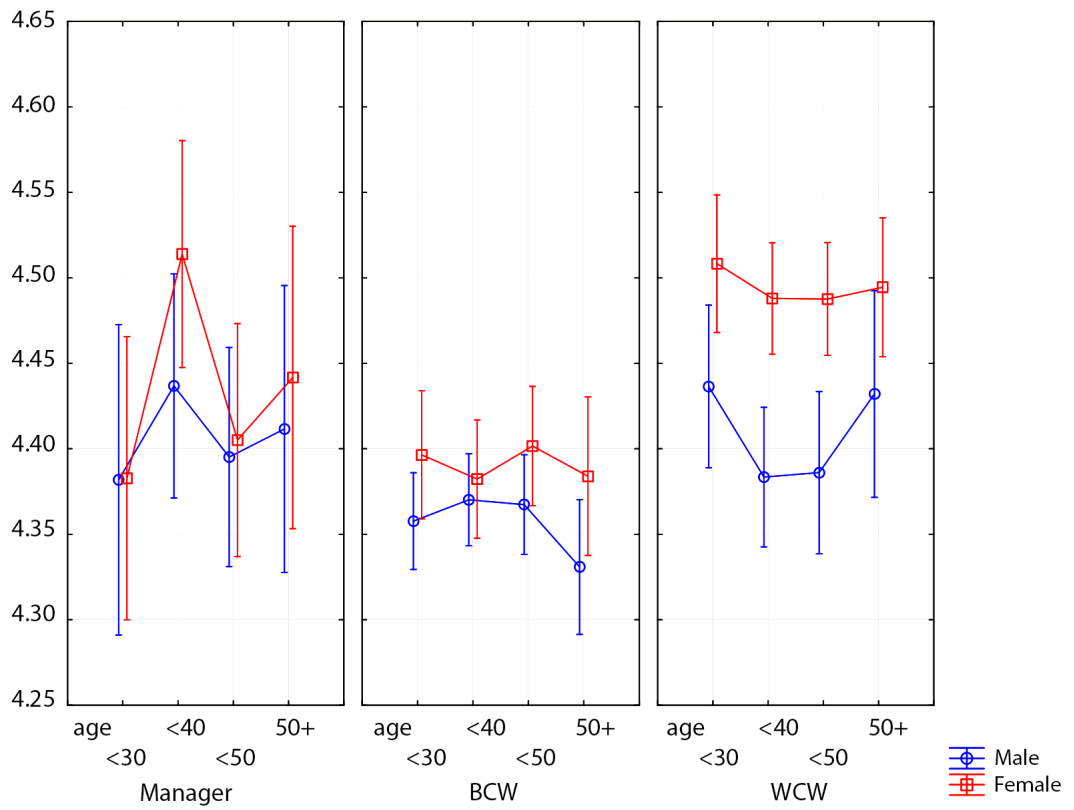

Figure 2. Tukey's HSD test for motivation factor fair appraisal system

Following the results of the research conducted using the sample set consisting of more than 34,000 employees it can be stated that Slovak employees are motivated to improve the job performance especially by basic salary and fair appraisal system. Similar results are presented in the research of Hondgesberg (2013). The results show that basic salary was perceived as the most important motivation factor by employees in Germany, Great Britain, Japan, South Africa, Italy. As well as 39\% of Austrian employees considered basic salary the most important motivation factor (Monster, 2009).

The results of the research show that basic salary is regarded as the most important motivation factor relating to finance affecting the motivation of the Slovak employees. The motivation factor basic salary was investigated individually with the focus on gender, age, job position using the Tukey's HSD test. Following the results, it can be seen that significant differences in the motivation factor basic salary were caused by gender, age and job position as well as mutual interaction of gender and job position. 
The motivation factor fair appraisal system shows the major statistically significant differences. The differences were due to mutual interaction of the age and job position. The differences were identified mainly between women - white collar workers and men - blue collar workers. Following the results, it can be stated that fair appraisal system is missing in mentioned job positions in Slovakia.

Owing to the effective motivating the employees, mentioned issue was spread by another variables affecting the level of motivation. For example, gender and the age of employees must be taken into account within the human resource strategy. It is confirmed by present research studies of Malchrowicz-Mośko et al. (2019), Fapohunda (2017), Peterson (2004), Bailyn (1993) and Buttner (1993). According to them, motivation is affected by gender. Other research studies (Hayes et al., 2018; King et al., 2017; Joniakova \& Blstakova, 2015; Singh, 2014; Kaylene et al., 2010; Zemke et al., 2000; Deal, 2007; Freund, 2006) confirm that motivation is affected by the age as well. However, the approach of managers to employee motivation must be different also in other social areas for example in the case of job position. It is confirmed by the research of Brady and King (2018) and Fernández-Muñoz and Topa (2018).

The research shows that the hypothesis in which it is supposed that the motivation needs of employees of different gender, age, and job position are different was confirmed. Following the results obtained using the Tukey's test, the conclusion that Slovak employees - men in the job position as a blue-collar worker and women - white-collar workers are not satisfied with the finances can be drawn. They attach the greatest weight to this motivation factor. The motivation factor basic salary was ranked first in terms of effective employee motivation.

\section{Conclusions}

Motivation is one of the prerequisites to improve the effectiveness of job performance in an enterprise. An ability to motivate in the area of human potential management is perceived by the authors as the most important and at the same time the most complicated skill of a supervisor. Employees play a significant role in a business success and are more important than capital power and technologies used in the company. Their motivation is a key to success. Knowledge about employee motivation allow managers to take actions to improve employee performance in the workplace. Managers must be familiar with the employee motivation. It is a complex and goal-directed effort of a manager to create the work environment and atmosphere meeting inner aspirations, needs and interests of employees and encouraging their activity in a desired way. When motivating, the fact that employees are completely different must be taken into account. Their needs differ and they are motivated by different motivation factors. Apart from that fact, gender, age, job positions and other factors affecting the needs of individuals must be taken into consideration as well.

The following facts are the limiting circumstances of the research results presented. Due to the limitation in the scope of the contribution, only two most important motivation factors relating to finance, basic salary and fair appraisal system, were analysed from the scale of a wide range of thirty motivation factors. 
The conclusion that the motivation of employees of different gender, age and job position could differ due to the current situation resulting from a global pandemic can be drawn. As the collection, selection and evaluation of data took place before the global pandemic, it is planned to address the current situation in future direction of research.

\section{Acknowledgements}

The research was supported by KEGA 005TU Z-4/2020.

\section{Author contributions}

MH, SL, MP, ŽB and ZC conceived the study and were responsible for the design and development of the data analysis. MH, SL, MP, ŽB and ZC were responsible for data collection and analysis. MH, SL, MP and Ž MH, SL, MP, ŽB and ZC B were responsible for data interpretation. $\mathrm{MH}, \mathrm{SL}, \mathrm{MP}, \check{\mathrm{Z}} \mathrm{B}$ and $\mathrm{ZC}$ wrote the first draft of the article.

\section{Disclosure statement}

Authors declare no financial, professional, and personal interests from other parties.

\section{References}

Almobaireek, W. N., \& Manolova, T. S. (2013). Entrepreneurial motivations among female university youth in Saudi Arabia. Journal of Business Economics and Management, 14(Suppl 1), S56-S75. https://doi.org/10.3846/16111699.2012.711364

Anguelov, K., Stoyanova, T., \& Tamošiūnienè, R. (2020). Research of motivation of employees in the IT sector in Bulgaria. Entrepreneurship and Sustainability Issues, 7(3), 2556-2567. https://doi.org/10.9770/jesi.2020.7.3(73)

Ayub, N. (2010). Effect of intrinsic and extrinsic motivation on academic performance. Pakistan Business Review, 363-372.

Bailyn, L. (1993). SMR forum: Patterned chaos in human resource management. Sloan Management Review, 34(2), 77-83.

Bakotic, D., \& Babic, T. B. (2013). Relationship between working conditions and job satisfaction: The case of Croatian shipbuilding company. International Journal of Business and Social Science, 4(2), 206-213.

Brady, P. Q., \& King, W. R. (2018). Brass satisfaction: Identifying the personal and work-related factors associated with job satisfaction among police chiefs. Police Quarterly, 21(2), 250-277. https://doi.org/10.1177/1098611118759475

Buttner, E. H. (1993). Female entrepreneurs: How far have they come? Business Horizons, 36(2), 59-65. https://doi.org/10.1016/S0007-6813(05)80039-4

Cakir, O., \& Kozak, M. A. (2017). Designing and effective organizational employee motivation system based on ABCD model for hotel establishments. Tourism and Hospitality Management, 23(1), 69-86. https://doi.org/10.20867/thm.23.1.6

Chatzopoulou, M., Vlachvei, A., \& Monovasilis, Th. (2015). Employee's motivation and satisfaction in light of economic recession: evidence of Grevena Prefecture-Greece. Procedia Economics and Finance, 24, 136-145. https://doi.org/10.1016/S2212-5671(15)00633-4 
Damij, N., Levnajić, Z., Skrt, V. R., \& Suklan, J. (2015). What motivates us for work? Intricate web of factors beyond money and prestige. PLoS ONE, 10(7), e0132641. https://doi.org/10.1371/journal.pone.0132641

Dar, A. T., Bashir, M., Ghazanfar, F., \& Abrar, M. (2014). Mediating role of employee motivation in relationship to post-selection HRM practices and organisational performance. International Review of Management and Marketing, 4(3), 224-238.

Deal, J. J. (2007). Retiring the generation gap: How employees young and old van find common ground. Jossey-Bass, San Francisco, CA, USA.

Diefendorff, J. M., \& Seaton, G. A. (2015). Work motivation. In International encyclopedia of the social \& behavioral sciences ( $2^{\text {nd }}$ ed., pp. 680-686). Elsevier. https://doi.org/10.1016/B978-0-08-097086-8.22036-9

Faletar, J., Jelačić, D., Sedliačiková, M., Jazbec, A., \& Hajdúchová, I. (2016). Motivation employees in a wood processing company before and after restructuring. BioResources, 11(1), 2504-2515. https://doi.org/10.15376/biores.11.1.2504-2515

Fapohunda, T. M. (2017). Gender and impression management in the workplace. Acta Oeconomica Universitatis Selye, 6(2), 47-56.

Fernández-Muñoz, J. J., \& Topa, G. (2018). Older workers and affective job satisfaction: Gender invariance in Spain. Frontiers in Psychology, 9, 930. https://doi.org/10.3389/fpsyg.2018.00930

Freund, A. M. (2006). Age-differential motivational consequences of optimization versus compensation focus in younger and older adults. Psychology and Aging, 21(2), 240-252.

https://doi.org/10.1037/0882-7974.21.2.240

Guay, F., Chanal, J., Ratelle, C. F., Marsh, H. W., Larose, S., \& Boivin, M. (2010). Intrinsic, identified, and controlled types of motivation for school subjects in young lementary school children. British Journal of Educational Psychology, 80(4), 711-735. https://doi.org/10.1348/000709910X499084

Hayes, J. B., Parks, C. P., McNeilly, S., \& Johnson, P. (2018). Boomers to millennials: Generational stereotypes at work in academic librarianship. The Journal of Academic Librarianship, 44(6), 845-853. https://doi.org/10.1016/j.acalib.2018.09.011

Hitka, M. (2009). Model analýzy motivácie zamestnancov výrobných podnikov [Model of analysis of motivation of employees of manufacturing enterprises]. Technická univerzita vo Zvolene, Slovakia.

Hitka, M., Lipoldová, M., \& Schmidtová, J. (2020). Employees' motivation preferences in forest and wood-processing enterprises. Acta Facultatis Xylologiae Zvolen, 62(1), 151-164. https://doi.org/10.17423/afx.2020.62.1.13

Hondgesberg, R. (2013). Encouraging motivation of employees. Fleischwirtschart, 93(7), 39-41.

Joniakova, Z., \& Blstakova, J. (2015). Age management as contemporary challenge to human resources management in Slovak companies. Procedia Economics and Finance, 34, 202-209. https://doi.org/10.1016/S2212-5671(15)01620-2

Jung, H. S., Seo, K. H., \& Yoon, H. H. (2020). The importance of leader integrity on family restaurant employees' engagement and organizational citizenship behaviors: Exploring sustainability of employees' generational differences. Sustainability, 12(6), 2504. https://doi.org/10.3390/su12062504

Kamalian, A. R., Yaghoubi, N. M., \& Moloudi, J. (2010). Survey of relationship between organizational justice and empowerment (A case study). European Journal of Economics, Finance and Administrative Sciences, 24, 165-171.

Kampf, R., \& Lizbetinova, L. (2015). The identification and development of talents in the environment of logistics companies. Nase More, 62(3), 139-142. https://doi.org/10.17818/NM/2015/SI9

Kampkötter, P. (2014). Performance appraisals and job satisfaction. The International Journal of Human Resource Management, 28(5), 750-774. https://doi.org/10.1080/09585192.2015.1109538

Kaylene, C. W., Robert, A. P., Alfred, R. P., \& Edward, H. H. (2010). Multi-generational marketing: Descriptions, characteristics, lifestyles, and attitudes. Journal of Applied Business and Economics, 11(2). 
King, C., Murillo, E., \& Lee, H. (2017). The effects of generational work values on employee brand attitude and behavior: A multi-group analysis. International Journal of Hospitality Management, 66, 92-105. https://doi.org/10.1016/j.ijhm.2017.07.006

Kohnová, L., Papula, J., \& Salajová, N. (2019). Internal factors supporting business and technological transformation in the context of industry 4.0. Business: Theory and Practice, 20, 137-145. https://doi.org/10.3846/btp.2019.13

Kropivšek, J., Jelačić, D., \& Grošelj, P. (2011). Motivating employees of Slovenian and Croatian woodindustry companies in times of economic downturn. Drvna Industrija, 62(2), 97-103. https://doi.org/10.5552/drind.2011.1040

Kucharčíková, A., \& Mičiak, M. (2018). Human capital management in transport enterprises with the acceptance of sustainable development in the Slovak Republic. Sustainability, 10(7), 2530. https://doi.org/10.3390/su10072530

Kumar, N. S., Haque, M. I., \& Venugopal, K. (2019). Employment challenges in Saudi Arabia: An attitudinal study. Entrepreneurship and Sustainability Issues, 6(4), 1637-1646. https://doi.org/10.9770/jesi.2019.6.4(6)

Laužikas, M., \& Miliūtè, A. (2020). Impacts of modern technologies on sustainable communication of civil service organizations. Entrepreneurship and Sustainability Issues, 7(3), 2494-2509. https://doi.org/10.9770/jesi.2020.7.3(69)

Linhartová, L, \& Urbancová, H. (2012). Results of analysis of employee mobility: Factors affecting knowledge continuity. Acta Universitatis Agriculturae et Silviculturae Mendelianae Brunensis, 60(4), 235-244. https://doi.org/10.11118/actaun201260040235

Malchrowicz-Mośko, E., Młodzik, M., León-Guereño, P., \& Adamczewska, K. (2019). Male and female motivations for participating in a mass cycling race for amateurs. The Skoda bike challenge case study. Sustainability, 11(23), 6635. https://doi.org/10.3390/su11236635

Miklosik, A., Evans, N., Zak, S., \& Lipianska, J. (2019). A framework for constructing optimisation models to increase the visibility of organizations' information in search engines. Information Research-an International Electronic Journal, 24(1), 808. http://www.informationr.net/ir/24-1/paper808.html

Miklosik, A., Kuchta, M., \& Zak, S. (2018). Monetising content through delivery of advertisements: The case of ad blockers. Ad Alta-Journal of Interdisciplinary Research, 8(1), 175-179.

Monster. (2009). Survey. Research report. http://karriere-journal.monster.lu/beruf-recht/chef-kollegen/ umfrage-mai/article.aspx

Moresová, M., Sedliačiková, M., Štefko, J., \& Benčiková, D. (2019). Perception of wooden houses in the Slovak Republic. Acta Facultatis Xylologiae Zvolen, 61(2), 121-135. https://doi.org/10.17423/Afx.2019.61.2.12

Nedeliaková, E., Kuka, A., Sulko, P., \& Hranický, M. (2018). An innovative approach to monitoring the synergies of extraordinary events in rail transport [Conference Presentation]. 22nd International Scientific on Conference Transport Means 2018, Trakai, Lithuania.

Niermann, P. F. J., \& Schmutte, A. M. (2014). Exzellente management enschidungen. Springer, Wiesbaden. https://doi.org/10.1007/978-3-658-02246-4

Palus, H., Parobek, J., Dzian, M., Simo-Svrcek, S., \& Krahulcova, M. (2019). How companies in the wood supply chain perceive the forest certification. Acta Facultatis Xylologiae Zvolen, 61(1), 155-165. https://doi.org/10.17423/afx.2019.61.1.15

Peterson, M. (2004). What men and women value at work: Implications for workplace health. Gender Medicine, 1(2), 106-124. https://doi.org/10.1016/S1550-8579(04)80016-0

Piotrowska, M. (2019). Facets of competitiveness in improving the professional skills. Journal of Competitiveness, 11(2), 95-112. https://doi.org/10.7441/joc.2019.02.07 
Pogodina, T., V., Muzhzhavleva, T. V., \& Udaltsova, N. L. (2020). Strategic management of the competitiveness of industrial companies in an unstable economy. Entrepreneurship and Sustainability Issues, 7(3), 1555-1564. https://doi.org/10.9770/jesi.2020.7.3(9)

Potkány, M., Debnár, M., \& Škultétyová, M. (2019). Life cycle cost analysis for reference prototype building in alternatives of silicate and wood-based structure. Acta Facultatis Xylologiae Zvolen, 61(2), 137-152. https://doi.org/10.17423/afx.2019.61.2.13

Remenova, K., \& Jankelova, N. (2019). How successfully can decision-making style predict the orientation toward well- or ill-structured decision-making problems. Journal of Competitiveness, 11(1), 99-115. https://doi.org/10.7441/joc.2019.01.07

Sheehan, C., De Cieri, H., Cooper, B., \& Shea, T. (2016). Strategic implications of HR role management in a dynamic environment. Personnel Review, 45(2), 353-373. https://doi.org/10.1108/PR-04-2014-0071

Singh, A. (2014). Challenges and issues of generation Y. Journal of Business and Management, 16(7), 59-63. https://doi.org/10.9790/487X-16715963

Stacho, Z., Stachová, K., \& Raišienè, A. G. (2019). Change in approach to employee development in organizations on a regional scale. Journal of International Studies, 12(2), 299-308. https://doi.org/10.14254/2071-8330.2019/12-2/19

Stachova, K., Stacho, Z., Blštáková, J., Hlatká, M., \& Kapustina, L. M. (2018). Motivation of employees for creativity as a form of support to manage innovation processes in transportation-logistics companies. Naše More, 65(4), 180-186. https://doi.org/10.17818/NM/2018/4SI.3

Štarchoň, P., Weberová, D., \& Ližbetinová, L. (2017). Clustering Czech consumers according to their spontaneous awareness of foreign brands [Conference presentation]. 29th International Business Information Management Association Conference Education Excellence and Innovation Management through Vision 2020: From Regional Development Sustainability to Global Economic Growth, Vienna, Austria.

Szierbowski-Seibel, K. (2018). Strategic human resource management and its impact on performance do Chinese organizations adopt appropriate HRM policies? Journal of Chinese Human Resource Management, 9(2), 62-76. https://doi.org/10.1108/JCHRM-07-2017-0017

Williams, R. (2013). How to motivate employees. Psychology Today. New York, USA.

Yukseloglu, S. M., \& Karaguven, M. H. (2013). Academic motivation levels of technical high schools students. Procedia - Social and Behavioral Sciences, 106, 282-288. https://doi.org/10.1016/j.sbspro.2013.12.033

Zaborova, E. N., Glazkova, I. G., \& Markova, T. L. (2017). Distance learning: Students' perspective. Sotsiologicheskie Issledovaniya, 2, 131-139.

Zemke, R., Raines, C., \& Filipczak, B. (2000). Generations at work. Amacom, New York. 